Article

\title{
Ensuring the Continuity of Power Supply to the On-Board Auxiliary Devices of the Trolleybus through the Recuperation of Kinetic Energy
}

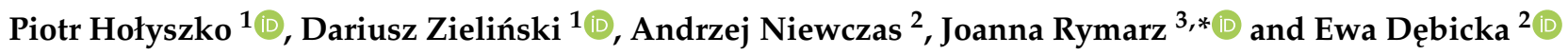 \\ 1 Department of Electrical Drives and Machines, Faculty of Electrical Engineering and Computer Science, \\ Lublin University of Technology, 38 Nadbystrzycka St., 20-618 Lublin, Poland; \\ pholyszko@mpk.lublin.pl (P.H.); d.zielinski@pollub.pl (D.Z.) \\ 2 Motor Transport Institute, 80 Jagielonska St., 03-301 Warsaw, Poland; andrzej.niewczas@its.waw.pl (A.N.); \\ ewa.debicka@its.waw.pl (E.D.) \\ 3 Department of Sustainable Transport and Powertrains, Faculty of Mechanical Engineering, Lublin University \\ of Technology, 38 Nadbystrzycka St., 20-618 Lublin, Poland \\ * Correspondence: j.rymarz@pollub.pl
}

Citation: Hołyszko, P.; Zieliński, D.; Niewczas, A.; Rymarz, J.; Dębicka, E. Ensuring the Continuity of Power Supply to the On-Board Auxiliary Devices of the Trolleybus through the Recuperation of Kinetic Energy. Energies 2021, 14, 5035. https:// doi.org/10.3390/en14165035

Academic Editor: Adel Merabet

Received: 13 July 2021

Accepted: 6 August 2021

Published: 17 August 2021

Publisher's Note: MDPI stays neutral with regard to jurisdictional claims in published maps and institutional affiliations.

Copyright: (c) 2021 by the authors. Licensee MDPI, Basel, Switzerland. This article is an open access article distributed under the terms and conditions of the Creative Commons Attribution (CC BY) license (https:// creativecommons.org/licenses/by/ $4.0 /)$.

\begin{abstract}
When a trolleybus travels through insulated sections of the overhead contact line, it experiences momentary power interruptions, which adversely affect the vehicle's on-board auxiliary subassemblies. To reduce these negative effects, one can harness energy recovered via regenerative braking. A model power supply circuit diagram for structural systems of the trolleybus is proposed. Simulation tests were carried out to develop a method for analyzing power supply to trolleybus auxiliary devices and verify it in a real-life example. The results allow determination of the limit power that can be generated by the trolleybus drive system to feed auxiliary devices during interruptions in power supply from the overhead contact line. The possibility of powering the on-board auxiliary equipment of a trolleybus using energy from recuperation with a traction motor is presented.
\end{abstract}

Keywords: trolleybus power supply system; power interruptions; on-board auxiliary devices; continuity of power supply

\section{Introduction}

Issues related to electromobility in public transport systems and the improvement of the operational efficiency of public transport are currently of interest to many scientists and engineers [1-6]. This coincides with the development of devices ensuring passenger comfort, greater passenger comfort expectations and the intensive advancement of technologies involved in the production of traction batteries [7,8], supercapacitors [9-12], combustion generators and other energy sources $[9,13,14]$.

The installation of stationary supercapacitors allows the recovery of braking energy for increased energy efficiency, as well as a better pantograph voltage profile $[10,15]$. The authors determined the basic characteristics of this type of device, characterized by high power density. The storage system parameters were determined using an optimization technique. The paper [9] presents a comparative study that was conducted to select the most suitable control strategy for high power electric vehicles powered by FC, battery and a supercapacitor (SC).

The actual problem of energy management in traction systems is presented in the paper [16]. A study was conducted on the use of recuperative braking energy of subways in electric transportation. Technical advantages, such as, for example, reducing the voltage fluctuations of the contact line, and economic advantages were presented.

In paper [1], the authors proposed and analyzed new strategies to increase the energy efficiency of an urban transportation network powered by a catenary. A simulation tool was developed to determine the energy efficiency of the global transport system (vehicles, 
power line and substation). Simulation results, with and without on-board energy storage and with high resistive overhead lines, are also presented. It is proven that using high line resistance instead of standard line resistance increases the efficiency of the overall system by an additional $5 \%$.

When a trolleybus runs connected to the grid, all its components are powered by the overhead line. However, because the overhead line has to be divided into sections and because it is fitted with switches, crossings and exits, the trolleybus temporarily loses power when running through section (catenary) insulators. As a result, the systems that feed auxiliary circuits are switched off, to be switched on again after a short time. This is undesirable, since power interruptions give rise to high electrical and mechanical overloads, which have a negative effect on the reliability of the vehicle's sub-assemblies. Moreover, recharging of the DC link capacitors used in the inverter at the input to the trolleybus static converter generates surge currents, which also reduces the service life of vehicle components [17].

Several methods are currently used to ensure the continuity of power supply to auxiliary devices during the passage of a trolleybus through section insulators $[17,18]$. The most common devices employed for this purpose are additional hydraulic pumps, mounted on the traction-motor shaft, which, however, only support the operation of hydraulic systems. On-board $24 \mathrm{~V}$ DC batteries are also used to power converters supplying power to auxiliary assembles, but such systems have many limitations. Another method is to use a supercapacitor storage unit, with converters in the intermediate circuit of the static converter, responsible for supplying power to the auxiliary circuits of the trolleybus [19]. However, this solution requires the use of a static converter that has a much more complex structure and is far more costly. Each trolleybus that is put into service, today, has a drive system that allows the recovery of energy during braking. It therefore only seems reasonable that this energy be employed to power auxiliary devices.

In this light, a new research question must be addressed, as to whether the energy generated as a result of regenerative braking of a trolleybus could be used to power auxiliary devices installed in the trolleybus when it is driving through insulated sections of the overhead contact line. This problem was analysed in the present study. A mathematical model of the trolleybus traction-motor load was developed. It was implemented in Matlab and Simulink.

\section{Trolleybus Overhead Power Supply Network}

When a trolleybus is running in contact with catenary wires, all its components are supplied from the overhead contact line. Because the network has to be broken into sections and includes switches, crossings and exits, the trolleybus loses power when running through dead zones for as long as $3 \mathrm{~s}$ or more [20].

The supply voltage of a trolleybus may vary from 400 to $800 \mathrm{~V}$. Figure 1 shows a view of a wire switch, installed in the overhead contact line. The smaller the angle, shown in the figure, the longer the interruption in power supply lasts. The dead section $\mathrm{d}$ can be up to $4 \mathrm{~m}$ long. The time a trolleybus travels without grid power depends on travelling speed, as shown in Table 1 and Figure 2 (red arrow). 


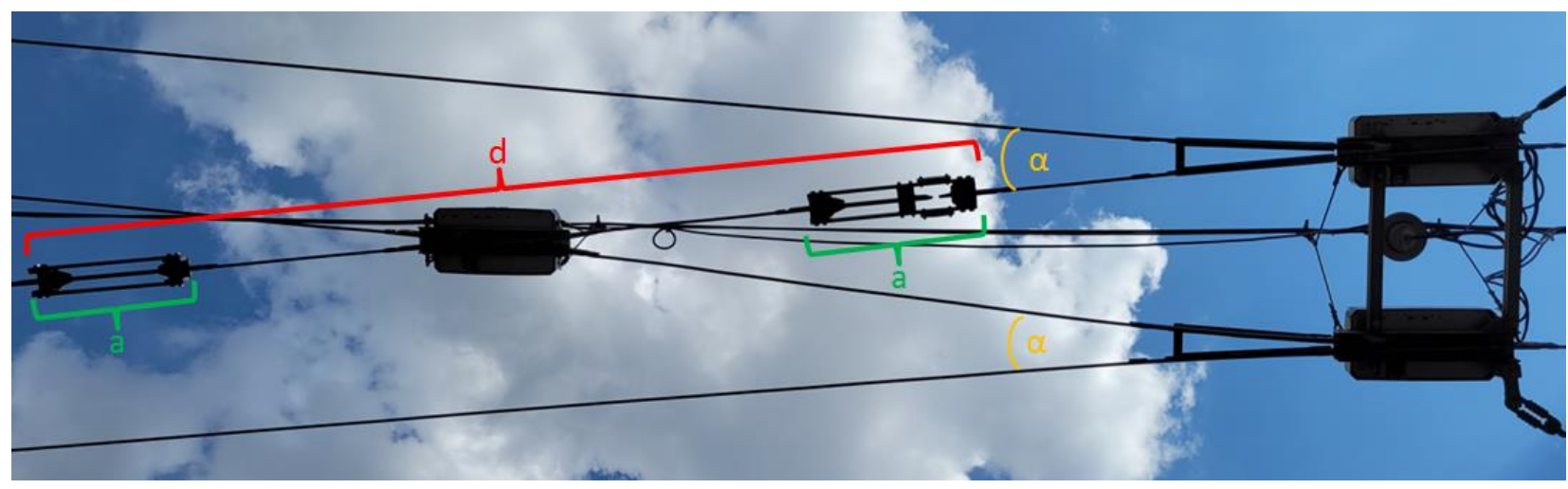

Figure 1. View of a trolleybus wire switch, showing the section of the network with no power supply, where: a denotes insulator zones and denotes a dead zone.

Table 1. Time a trolleybus travels through a $4[\mathrm{~m}]$ long insulator depending on trolleybus speed.

\begin{tabular}{cc}
\hline $\begin{array}{c}\text { Trolleybus Speed } \\
\boldsymbol{v}[\mathbf{k m} / \mathbf{h}]\end{array}$ & $\begin{array}{c}\text { Travel Time through the Insulator of the Overhead Contact } \\
\text { Line with a Length of } 4[\mathbf{m}] \boldsymbol{t}[\mathbf{s}]\end{array}$ \\
\hline 5 & 2.88 \\
10 & 1.44 \\
15 & 0.96 \\
20 & 0.72 \\
\hline
\end{tabular}

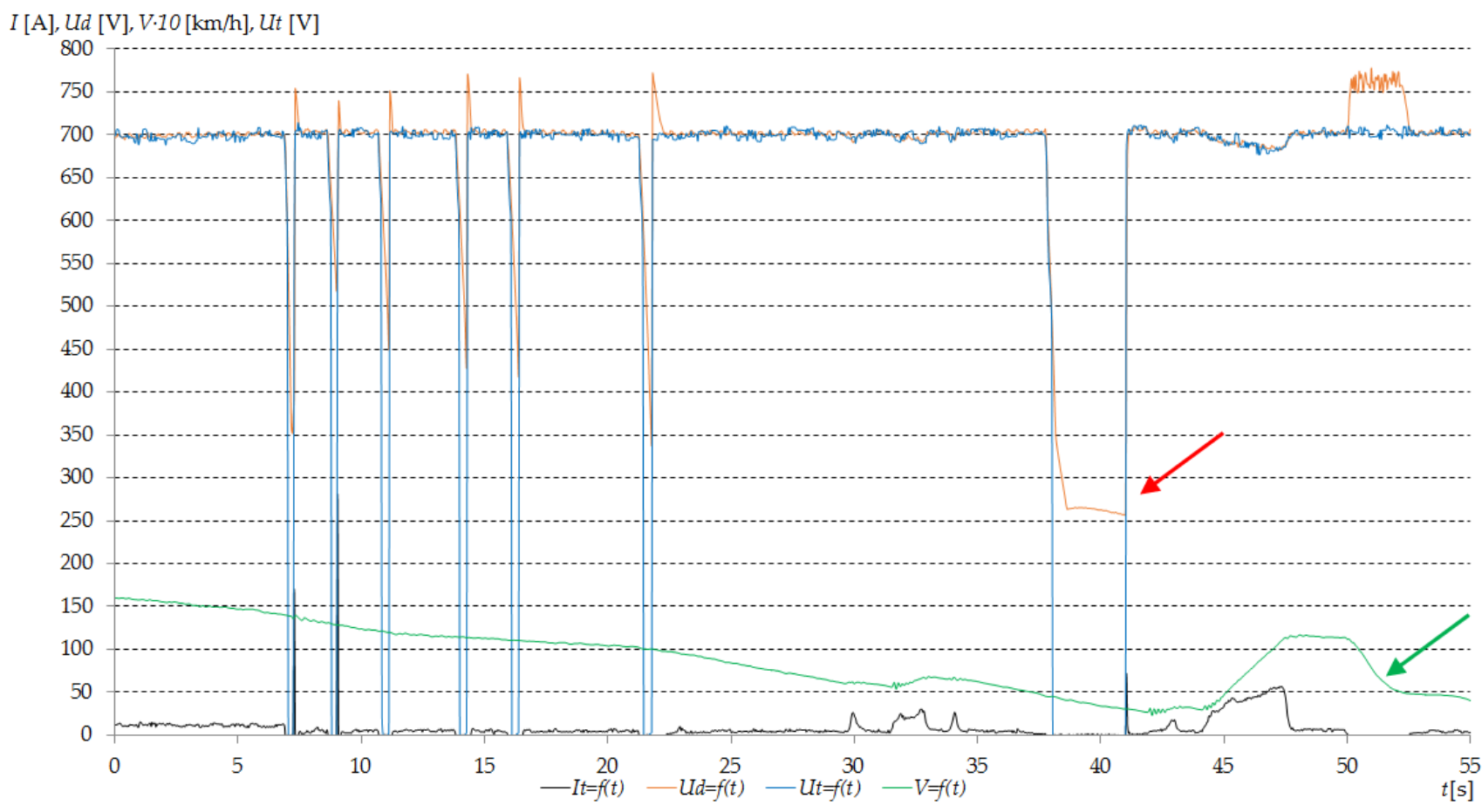

Figure 2. Curves of time vs. traction network current I [A] (black line), traction network voltage Ut [V] (blue line), trolleybus speed $($ scale $\times 0.1) \mathrm{v}[\mathrm{km} / \mathrm{h}]$ (green line), and traction inverter DC link voltage Ud [V] for a trolleybus passing through a series of section insulators [21].

Figure 2 shows curves of operational parameters during the passage of a trolleybus through a series of overhead contact line insulators. In the depot area, power interruptions occur very often due to the large number of devices installed on the overhead contact line. Figure 2 also shows how the traction inverter operates when a trolleybus is passing through insulated sections of the overhead contact line. At $38 \mathrm{~s}$, the traction system goes 
into the regenerative mode, maintaining the voltage on the inverter's DC links at $250 \mathrm{~V}$. All auxiliary devices are turned off at that time so that energy recuperation with the traction motor does not cause discomfort to the passengers and the driver, and so that regenerative braking can be used while the trolleybus is driving through an insulator [16].

\section{Functional and Formal-Legal Requirements for Trolleybus Auxiliary Devices}

Apart from the traction drive system, each trolleybus is equipped with auxiliary devices [22]. They include air conditioners, 24 [V] batteries along with a control system, a power steering pump, a heating boiler and an air compressor. These elements of equipment ensure the functionality of all systems installed in the trolleybus and maximize passenger comfort. The most important auxiliary devices are shown in Figure 3.

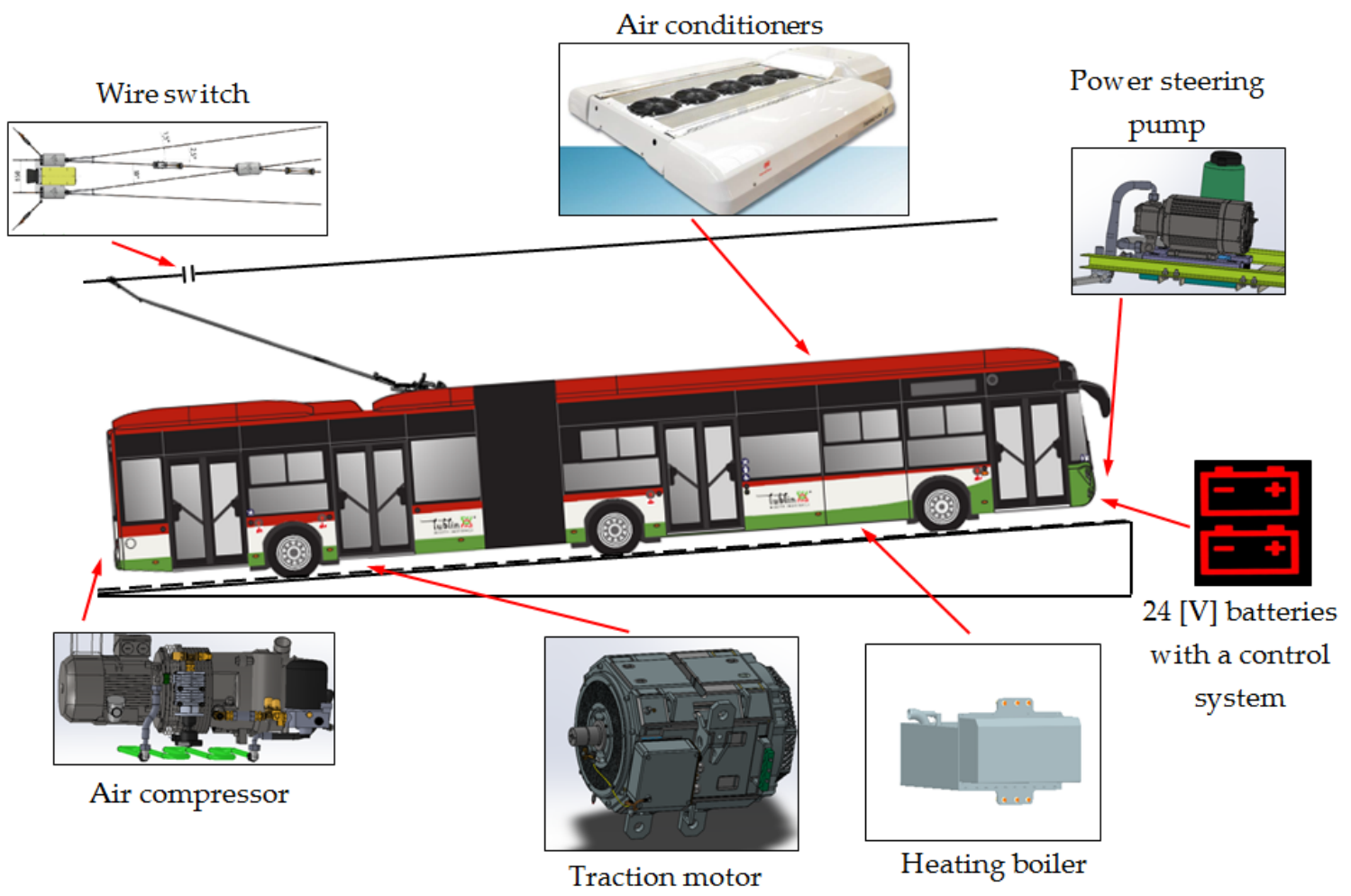

Figure 3. Components of trolleybus equipment; on-board auxiliary systems include air conditioners, 24 [V] batteries with a control system, a power steering pump, a heating boiler and an air compressor [21].

All auxiliary systems are powered by a static converter and other power electronic devices that provide a number of utility functions and meet the requirements for protection against electric shock. The auxiliary devices in the trolleybus can be supplied directly from the overhead contact line or from the DC links of the traction inverter [23]. When the trolleybus is powered from the overhead contact line, regardless of the operating mode of the drive, there is always a break in power supply to auxiliary devices during passage through a catenary insulator. Supplying power from traction inverter DC links increases trolleybus performance $[10,24]$. This is due to the fact that during regenerative braking, when the line voltage rises to $780 \mathrm{~V}$, the inverter system switches energy recovery from the overhead contact line to the braking resistor. In this situation, the energy generated by the traction motor also powers the auxiliary devices [25], as marked with the green arrow in Figure 2. A block circuit diagram of such a system is shown in Figure 4. 


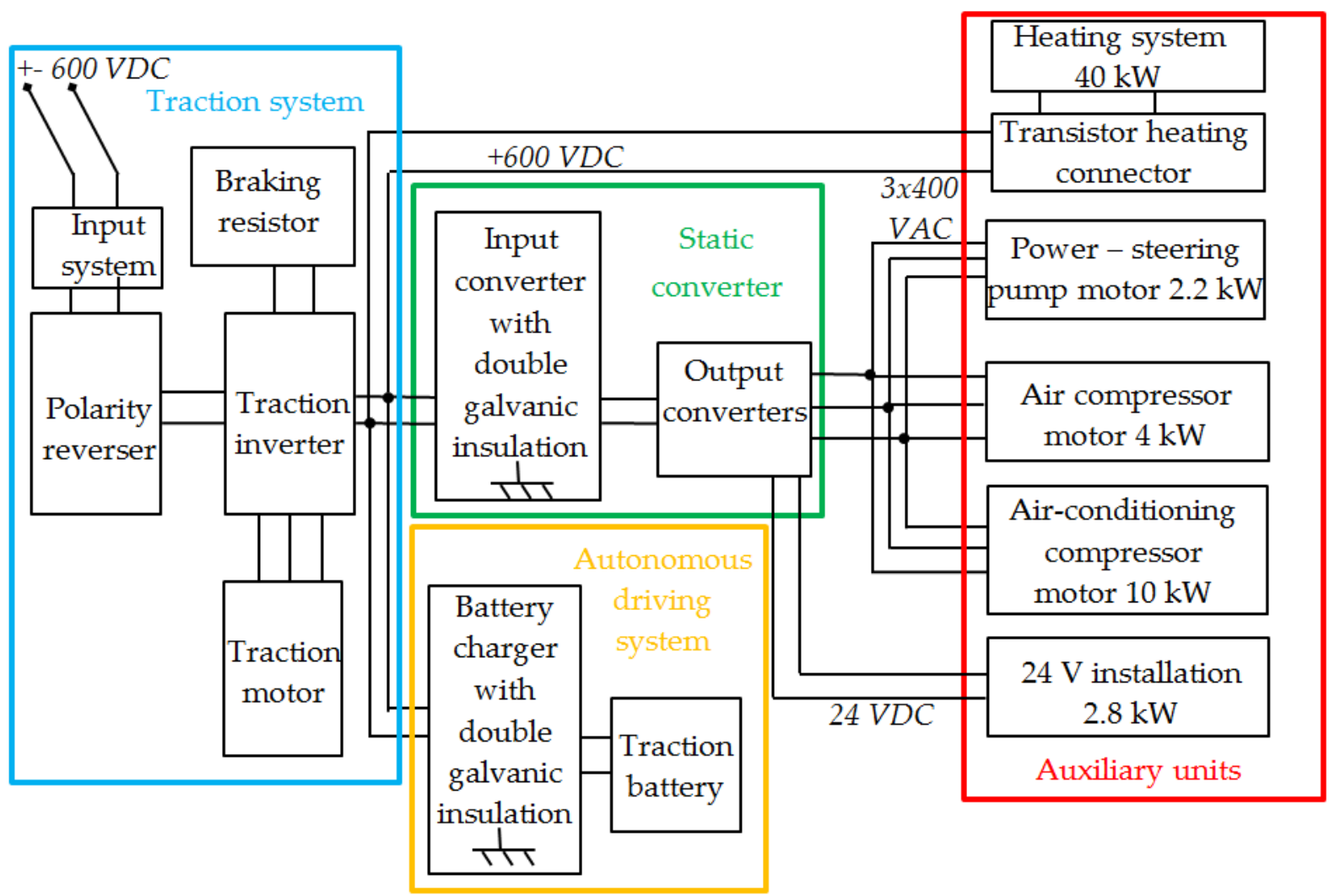

Figure 4. Block diagram of power supply to trolleybus drive and its auxiliary devices [21].

The block diagram proposed in this paper has been divided into four parts, with the individual components grouped by their functionality. The elements associated directly with the traction drive are referred to as the traction system. This system includes input devices such as a line choke, fuses, main contactors, a contactor for the pre-charge of the traction inverter capacitors and a line filter. The traction system also comprises a traction inverter, a resistor with a braking transistor and an asynchronous traction motor. The off-wire power system is fed from the traction inverter DC links. This system is part of a larger system responsible for supplying energy to the trolleybus when it is running off-wire. The traction inverter DC links also supply power to the heating system and the static converter, which feeds all auxiliary units other than the heating system.

\subsection{Functional Requirements}

Legal standards require that the power steering system be operative at all times. Whenever the trolleybus is passing through catenary insulators at speeds above $5 \mathrm{~km} / \mathrm{h}$, the power steering system must be operative for $10 \mathrm{~s}$. However ensuring the continuity of operation of the $24 \mathrm{~V}$ installation poses a huge problem even with short lasting power interruptions. The converter, which charges the $24 \mathrm{~V}$ on-board batteries, loses power when the trolleybus travels through a catenary insulator. During this time, the entire $24 \mathrm{~V}$ wiring is supplied with energy stored in the on-board batteries. This means the $24 \mathrm{~V}$ batteries need to be kept in pristine technical condition. The provisions of the legal standards regarding the operation of auxiliary devices for passage through section insulators of the overhead contact line are given in Table 2. 
Table 2. Power of trolleybus auxiliary devices and requirements for maintaining power supply during passage through catenary insulators [21].

\begin{tabular}{|c|c|c|c|}
\hline Auxiliary Devices & Power $[\mathrm{kW}]$ & $\begin{array}{l}\text { Functionality Required by } \\
\text { Standards/Additional Functionality }\end{array}$ & Power $[k W]$ \\
\hline power steering & 2.2 & required & 2.2 \\
\hline power supply to $24 \mathrm{~V}$ wiring & 2.8 & additional & \\
\hline compressed air system & 5 & additional & 17.8 \\
\hline $\begin{array}{l}\text { power supply to air conditioning } \\
\text { compressor }\end{array}$ & 10 & additional & \\
\hline total & & & 20 \\
\hline power supply to heating system & 40 & not required & 40 \\
\hline
\end{tabular}

Particular focus is placed on those equipment operation requirements that are necessary to meet the applicable standards. Attention is also paid to an additional functionality associated with the continuous operation of systems during runs through catenary insulators, which is not required by legal acts, but is crucial, since the devices are structured in such a way that a lack of power interruptions extends their service life and increases the comfort of passengers and the driver. When certain devices do not need to be powered while the trolleybus is driving through insulators, their functionality is marked as "not required". In accordance with [22], during service braking, deceleration must be lower than $2 \mathrm{~m} / \mathrm{s}^{2}$, and deceleration jerk must not exceed $1.5 \mathrm{~m} / \mathrm{s}^{3}$. Pursuant to [23], the supply voltage of a trolleybus must be within the range of $400-800 \mathrm{~V}$, while the nominal voltage $U$ of the overhead contact line should be $600 \mathrm{~V}$.

\subsection{Electric Shock Protection Requirements}

The supply voltage of the DC control wiring should not exceed $60 \mathrm{~V}$, and the cable nominal voltage of the three-phase auxiliary wiring should not be higher than $400 \mathrm{~V}$. The converter charging $24 \mathrm{~V}$ batteries should provide double-galvanic isolation from power supply circuits. The first stage of the isolation must have an insulating strength of $2.5 \mathrm{U}+$ $1500 \mathrm{~V}$. For the nominal voltage of the traction network of $600 \mathrm{VDC}$, the insulating strength is $3000 \mathrm{~V}$ for $1 \mathrm{~min}$. The second stage of the isolation must withstand an alternating test voltage of $2300 \mathrm{~V}$ for $1 \mathrm{~min}$.

The withstand voltage of the trolleybus's three-phase wiring against supply voltage must meet the requirements of the test for the first stage of isolation, while the withstand voltage, with respect to the mechanical mass of the trolleybus, must meet the requirements of the second stage of isolation test. The insulation resistance of the two isolation stages must not be less than $1.5 \mathrm{M} \Omega$ and $6 \mathrm{M} \Omega$, respectively, before the trolleybus is first put into service. For low-power motors, for which the insulation strength standard is $1800 \mathrm{~V}$ for $1 \mathrm{~min}$, the second stage of isolation cannot be provided only by insulating the motor windings. One of the solutions used is to place the motor on insulators. In such a case, it is necessary to ensure that the motor is separated from the device it drives or that the entire set of motors along with their devices are isolated from the vehicle's mechanical mass. In practice, such solutions do not work well due to operational problems with maintaining the required resistance at the level of $1.5 \mathrm{M} \Omega$. Therefore, an additional separating converter, with double isolation, is used (an intermediate circuit of the static converter, which already provides double isolation for the output converters that feed the auxiliary systems and for the $24 \mathrm{~V}$ on-board battery charger).

The autonomous driving system can be turned on after the trolleybus is disconnected from the current collectors using the main contactors. An installation with an autonomous energy source can have a single-stage isolation with the parameters of the second stage of isolation, provided that, when the motor is fed with power from the overhead contact line, it is separated by a charger providing the first stage of isolation. Because it is difficult to maintain the insulation parameters of the traction battery, and the procedure for testing the strength of battery insulation is very complicated, chargers are used that provide double 
galvanic isolation of the battery from the power supply circuits. In such cases, the battery is tested for insulation resistance against the mechanical mass of the trolleybus, which must be at least $100 \Omega / \mathrm{V}$.

\section{Analysis of the Possibility of Providing Power to On-Board Auxiliary Devices through Recuperation of the Kinetic Energy of the Trolleybus}

The motion resistances that the trolleybus traction motor must overcome are shown schematically in Figure 5. They are reflected back to the traction motor shaft. The mathematical model of the traction motor was used to develop a formula for the electromagnetic moment that overcomes these resistances.

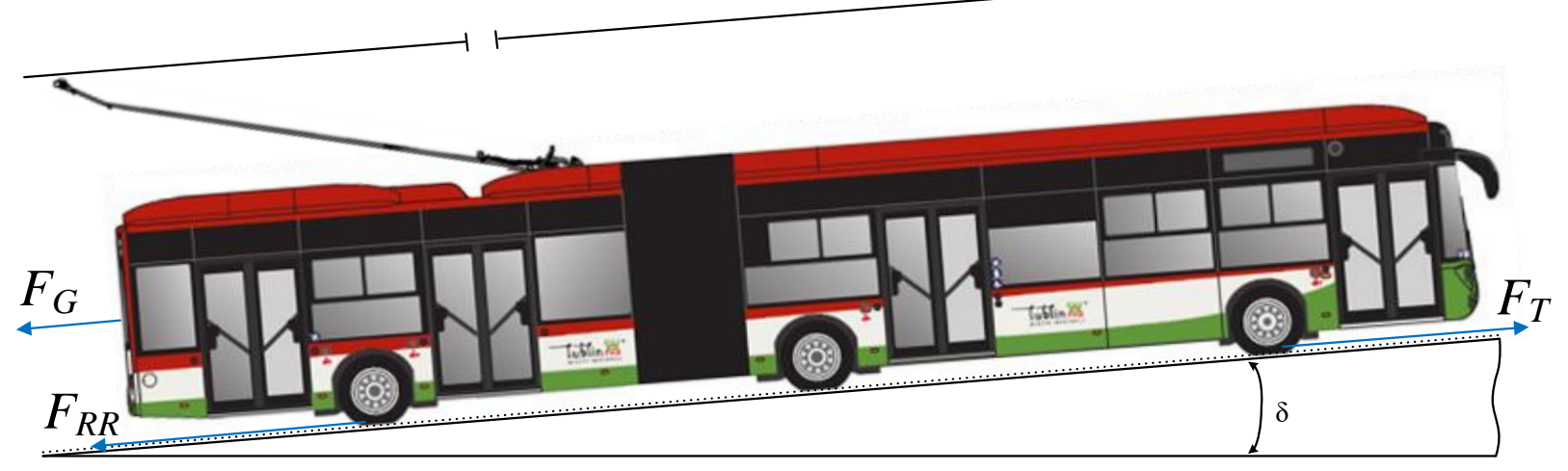

Figure 5. Forces acting on a trolleybus in motion.

The vehicle's linear motion is given by:

$$
F_{T}-F_{R R}-F_{G}=(m+d) \frac{d V}{d t}
$$

where: $F_{T}$ - traction force, $F_{R R}$-rolling resistance and air resistance, $F_{G}$ - gradient resistance, $m$-vehicle mass, $d$-mass moment of inertia caused by the masses of rotating parts, $V$-vehicle speed.

The kinetic energy of the vehicle is described by the following equation:

$$
E_{K}=\frac{m V^{2}}{2}+J_{s} \frac{\omega_{n}^{2}}{2}+n_{k} J_{k} \frac{\omega_{k}^{2}}{2}
$$

where: $\omega_{k}$-angular velocity of vehicle wheels, $\omega_{n}$-angular velocity of traction motor shaft, $J_{k}-$ moment of inertia of the wheel, $J_{s}$-moment of inertia of the traction motor rotor, $n_{k}$-number of vehicle wheels, including twin wheels.

Vehicle speed $V$ is related to the angular velocity of the wheels $\omega_{k}$ by the following equation:

$$
\omega_{k}=\frac{V}{r}
$$

where: $r$-wheel radius.

In turn, the angular speed of the traction motor shaft $\omega_{n}$ is associated with vehicle speed $V$ as follows:

$$
\omega_{n}=z \omega_{k} \rightarrow \omega_{n}=z \frac{V}{r}
$$

where: $z$-gear transmission ratio.

Thus, the equation that describes the vehicle's kinetic energy has the following form:

$$
E_{K}=\frac{m V^{2}}{2}+J_{s} \frac{z^{2} V^{2}}{2 r^{2}}+n_{k} J_{k} \frac{V^{2}}{2 r^{2}}
$$


hence:

$$
E_{K}=\frac{m V^{2}}{2}+\frac{V^{2}}{2 r^{2}}\left(J_{s} z^{2}+n_{k} J_{k}\right)
$$

after transformation, the following equation is obtained:

$$
E_{K}=\frac{V^{2}}{2}\left[m+\frac{1}{r^{2}}\left(J_{s} z^{2}+n_{k} J_{k}\right)\right]=\frac{V^{2}}{2}(m+d)
$$

where $d$ is the increase in vehicle mass due to rotating masses and equals

$$
d=\frac{1}{r^{2}}\left(J_{s} z^{2}+n_{k} J_{k}\right)
$$

Vehicle speed $V$ is related to the angular velocity of the traction motor's rotor $\omega_{\mathrm{n}}$ by the following equation:

$$
V=\omega_{n} \frac{r}{z}
$$

and so

$$
d V=\frac{r}{z} d \omega_{n}
$$

Substituting into Equation (1), we get:

$$
F_{T}-F_{R R}-F_{G}=(m+d) \frac{r}{z} \frac{d \omega_{n}}{d t}
$$

Traction torque $T_{T}$ is related to traction force $F_{T}$ by the following equation:

$$
T_{T}=F_{T} r
$$

At the same time, the traction torque is related to the driving torque of motor shaft:

$$
T_{T}=z\left(T_{E}-T_{z}\right)
$$

where: $T_{E}$-driving torque of motor shaft, $T_{Z}$-resistance torque of the transmission reflected back to the shaft side of the drive motor.

Hence:

$$
F_{T}=\frac{z}{r}\left(T_{E}-T_{z}\right)
$$

Rolling resistance and air resistance torque $T_{R R}$ is related to the resistance force $F_{R R}$ by the following equation:

$$
T_{R R}=F_{R R} r
$$

At the same time, torque $T_{R R}$ reflected back to the shaft of the drive motor is given by equation:

$$
T_{R R}^{\prime}=\frac{T_{R R}}{z}
$$

From this, the following equation is derived:

$$
F_{R R}=\frac{z}{r} T_{R R}^{\prime}
$$

Similarly, we obtain:

$$
F_{G}=\frac{z}{r} T_{G}^{\prime}
$$

where $T_{G}$-gradient torque reflected back to the side of the drive motor shafts.

By substituting the equations $F_{T}, F_{R R}$ and $F_{G}$ to formula (12), we get:

$$
\frac{z}{r}\left(T_{E}-T_{z}\right)-\frac{z}{r} T_{R R}^{\prime}-\frac{z}{r} T_{G}^{\prime}=(m+d) \frac{r}{z} \frac{d \omega_{n}}{d t}
$$


Multiplying both sides of the equation by $\frac{r}{z}$, we obtain:

$$
T_{E}-T_{z}-T_{R R}^{\prime}-T_{G}^{\prime}=(m+d) \frac{r^{2}}{z^{2}} \frac{d \omega_{n}}{d t}=J \frac{d \omega_{n}}{d t}
$$

where: $(m+d) \frac{r^{2}}{z^{2}}$ is a constant parameter representing the inertia of the vehicle $J$ reflected back to the drive motor shaft. When formula (8) is taken into account, the following is obtained:

$$
J=\frac{m r^{2}}{z^{2}}+J_{s}+\frac{1}{z^{2}} n_{k} J_{k}
$$

Coefficient $\frac{m r^{2}}{z^{2}}$ represents the moment of inertia of the vehicle reflected back to the shaft side of the drive motor.

Ultimately:

$$
T_{E}-T_{z}-T_{R R}^{\prime}-T_{G}^{\prime}=J \frac{d \omega_{n}}{d t}
$$

where:

$$
\begin{gathered}
J=\frac{m r^{2}}{z^{2}}+J_{s}+\frac{1}{z^{2}} n_{k} J_{k} \\
T_{G}^{\prime}=\frac{r}{z} F_{G} \\
T_{R R}^{\prime}=\frac{r}{z} F_{R R},
\end{gathered}
$$

Formula (22) describes the relationship between the electromagnetic moment of the traction motor and motion resistances.

The final value of motor load torque $T_{O}$ is given by the following equation:

$$
T_{O}=T_{z}+T_{R R}^{\prime}+T_{G}^{\prime}+J \frac{d \omega_{n}}{d t}
$$

On approximating, one obtains:

$$
\begin{gathered}
T_{Z}=T_{Z 0}+T_{Z Z} \\
T_{Z 0}=\beta\left(1-\eta_{Z N}\right) T_{E N} \\
T_{Z Z}=(1-\beta)\left(1-\eta_{Z N}\right) T_{E}
\end{gathered}
$$

where: $\beta$-coefficient of constant (no-load) losses, $T_{Z 0}-$ No-load loss torque of the transmission system, $T_{Z Z}$-variable-loss torque related to the transmission of torque $T_{E}$ by the torque transmission system, $T_{E N}$-nominal motor torque.

It was assumed, to simplify the calculations, that torque $T_{z z}$ was linearly dependent on transmitted torque $T_{E}$.

The efficiency of the transmission system was defined as:

$$
\begin{gathered}
\eta_{Z}=\frac{T_{E}-T_{Z 0}-T_{Z Z}}{T_{E}} \\
\eta_{Z}=\frac{\beta\left(T_{E}-T_{E N}\right)+\eta_{Z N}\left[\beta\left(T_{E N}-T_{E}\right)+T_{E}\right]}{T_{E}}
\end{gathered}
$$

The formula is valid for torques:

$$
T_{E} \geq \frac{\beta\left(1-\eta_{Z N}\right)}{\beta\left(1-\eta_{Z N}\right)+\eta_{Z N}} T_{E N}
$$

For a two-stage gear transmission system, it can be assumed that $\eta_{Z N}=0.95$ and $\beta=0.25$. 
A mechanical equation of the electric motor is:

$$
\frac{d \omega_{n}}{d t}=\left(T_{E}-T_{L}\right) \frac{1}{J}
$$

where: $T_{E}$-electromagnetic torque, $T_{L}$-load torque, $\omega_{n}$-angular velocity, $J$-moment of inertia.

A model of the two-level inverter is shown in Figure 6. Voltage vector $\vec{V}_{S}$ is generated from the following equation:

$$
\vec{V}_{s}=\sqrt{\frac{2}{3}} V_{d c}\left[S_{a}+S_{b} e^{j \frac{2 \pi}{3}}+S_{c} e^{j \frac{4 \pi}{3}}\right]
$$

where: $S_{a}, S_{b}, S_{c}$ are the inverter's three-phase switching functions, which can take the value of 1 or $0 ; V_{d c}$-inverter DC link voltage.

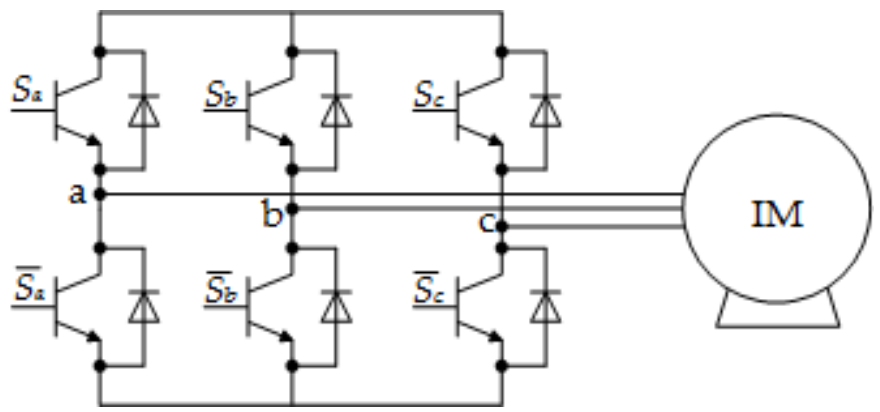

Figure 6. Circuit diagram of a three-phase star-connected induction motor powered from a two-level voltage source inverter [26].

Based on the model of an induction motor in a stationary reference frame, the stator flux equation, after Clarke transformation, can be expressed as follows:

$$
\left\{\begin{array}{l}
\phi_{s \alpha}=\int\left(v_{s \alpha}-R_{s} i_{s \alpha}\right) d t \\
\phi_{s \beta}=\int\left(v_{s \beta}-R_{s} i_{s \beta}\right) d t
\end{array}\right.
$$

where: $\phi_{s \alpha}, \phi_{s \beta}-\alpha$ and $\beta$ axis components of flux, $v_{s \alpha}, v_{s \beta}-\alpha$ and $\beta$ axis components of voltage, $i_{s \alpha}, i_{s \beta}-\alpha$ and $\beta$ axis components of current, $R_{S}-$ stator winding resistance.

Voltage components in axis $\alpha$ and $\beta v_{s \alpha}, v_{s \beta}$ are given by the following equation:

$$
\left\{\begin{array}{c}
v_{s \alpha}=\sqrt{\frac{2}{3}} V_{d c}\left[S_{a}-\frac{1}{2}\left(S_{b}+S_{c}\right)\right] \\
v_{s \beta}=\sqrt{\frac{1}{2}} V_{d c}\left(S_{b}-S_{c}\right)
\end{array}\right.
$$

Current components in axis $\alpha$ and $\beta i_{s \alpha}, i_{s \beta}$ are given by formula:

$$
\left\{\begin{array}{c}
i_{s \alpha}=\sqrt{\frac{3}{2}} i_{s \alpha} \\
i_{s \beta}=\frac{1}{\sqrt{2}}\left(i_{s b}-i_{s c}\right)
\end{array}\right.
$$

The rotor and stator flux vectors are related by equation:

$$
\phi_{r}=\frac{M}{L_{s}} \frac{1}{1+j \sigma \omega T_{r}} \phi_{s}
$$

where: $\phi_{r}, \phi_{s}$-stator and rotor flux vectors, $M$-stator-to-rotor mutual inductance, $\sigma$ Blondel coefficient, $L s$-stator inductance, $\omega$-angular velocity of the rotor, $T_{r}$-rotor torque. 
The angle between these two vectors is given by:

$$
\delta=\tan ^{-1}\left(\sigma \omega T_{r}\right)
$$

The general expression for electromagnetic torque is as follows:

$$
T_{E}=p \frac{M}{\sigma L_{s} L_{r}} \phi_{s} \phi_{r} \sin (\delta)
$$

where: $p$-number of pole pairs.

The stator flux amplitude is calculated on the basis of two components $\phi_{s \alpha}$ and $\phi_{s \beta}$.

$$
\phi_{s}=\sqrt{\phi_{s \alpha}^{2}+\phi_{s \beta}^{2}}
$$

The following formulas summarize the above analysis:

- Formula (26) describes the final value of motor load torque $T_{0}$

- Formula (40) describes the value of the traction motor's electromagnetic torque $T_{E}$ under DTC.

- $\quad$ Formula (22) describes the relationship between motor load torque $T_{0}$ and electromagnetic torque $T_{E}$

\section{Simulation Study}

In order to verify whether the auxiliary devices of the trolleybus could be powered using energy recuperated from regenerative braking with the traction motor [27], a trolleybus passage through a $4 \mathrm{~m}$ long catenary insulator was simulated numerically at speeds of 5,10 , 15 and $20 \mathrm{~km} / \mathrm{h}$, while maintaining passenger comfort conditions. The simulations were carried out in Matlab and Simulink, based on the circuit diagram of a trolleybus shown in Figure 7.

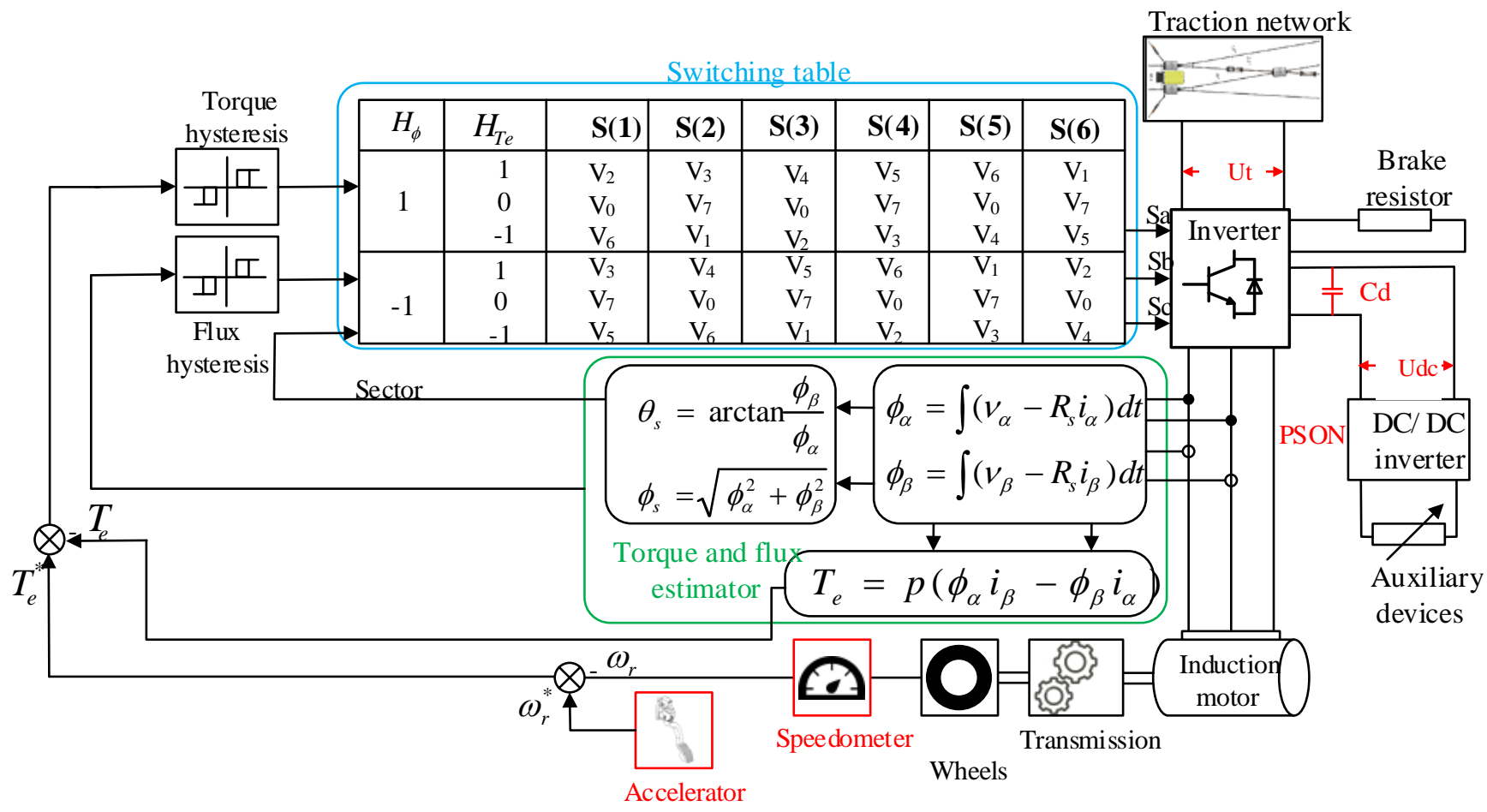

Figure 7. Circuit diagram of the trolleybus used in the simulation. 
A trolleybus with its traction system, electric drive and systems of converters and actuating systems and devices corresponding to the trolleybus equipment were modelled in accordance with Figure 4 . For the main drive system, a circuit diagram of an induction motor fed from a two-level traction converter with DTC was adopted [26]. The simulation algorithm is shown in Figure 8.

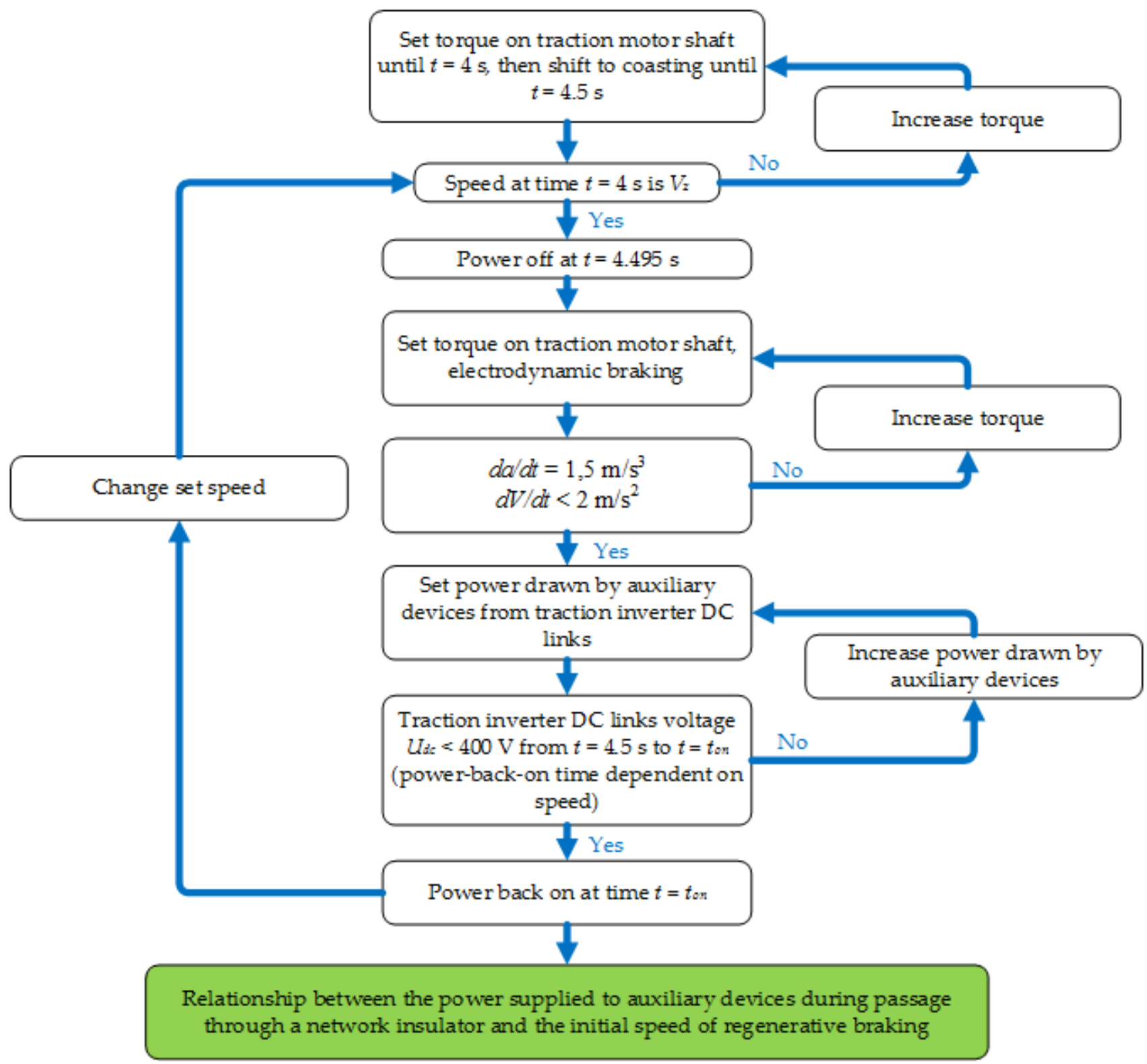

Figure 8. Simulation algorithm.

In compliance with the standards in force, it was assumed that the converters supplying power to auxiliary devices would switch off when the voltage on the DC links of the traction inverter $U_{d c}$ dropped below $400 \mathrm{~V}$ [28]. The simulations were performed for nominal line voltage. Torque was applied to the traction motor to accelerate the trolleybus to a speed at which the possibility of maintaining the operation of auxiliary devices was tested. At higher speeds, the travel time through a section insulator was correspondingly shorter, as shown in Table 1. Then, braking torque was applied to the traction motor, so as to ensure that passenger comfort was not affected. Any excess power was lost via the braking resistor, stabilizing the voltage on the DC links of the traction inverter to $780 \mathrm{~V}$. 
The simulations were carried out by increasing the load on the traction inverter DC links by increasing the power consumed by the auxiliary devices. The result of the simulation was positive for the load power of the DC links at which the converters did not switch off when the voltage dropped below $400 \mathrm{~V}$ as the trolleybus was passing through a section insulator. The parameters used in the simulation are given in Table 3.

Table 3. Trolleybus parameters and environmental variables used in the simulation study.

\begin{tabular}{|c|c|c|}
\hline Parameter & Value & Unit \\
\hline \multicolumn{3}{|c|}{ Trolleybus Parameters } \\
\hline mass & 17,600 & $\mathrm{~kg}$ \\
\hline air density & 1.2 & $\mathrm{~kg} / \mathrm{m}^{3}$ \\
\hline front surface area & 7 & $\mathrm{~m}^{2}$ \\
\hline drag coefficient & 0.4 & - \\
\hline rolling coefficient & 0.01 & - \\
\hline dynamic wheel radius & 0.464 & $\mathrm{~m}$ \\
\hline traction inverter dc link capacitance & 10 & $\mathrm{mF}$ \\
\hline drive axle efficiency & 0.95 & \\
\hline drive axle ratio & 6.2 & \\
\hline \multicolumn{3}{|c|}{ Environmental Parameters } \\
\hline roadway gradient & 0 & $\%$ \\
\hline wind speed & 0 & $\mathrm{~m} / \mathrm{s}$ \\
\hline \multicolumn{3}{|c|}{ Traction Motor Parameters } \\
\hline nominal power & 240 & $\mathrm{~kW}$ \\
\hline nominal voltage & 400 & $\mathrm{~V}$ \\
\hline nominal frequency & 60 & $\mathrm{~Hz}$ \\
\hline moment of inertia of the rotor & 4.2 & $\mathrm{kgm}^{2}$ \\
\hline number of pole pairs & 3 & \\
\hline \multicolumn{3}{|c|}{ Overhead contact line parameters } \\
\hline nominal voltage & 600 & $\mathrm{~V}$ \\
\hline maximum voltage & 800 & $\mathrm{~V}$ \\
\hline minimum voltage & 400 & $\mathrm{~V}$ \\
\hline
\end{tabular}

\section{Results of Simulation Experiments}

Maintenance of the operation of auxiliary devices was simulated during the passage of a trolleybus through catenary insulators at different driving speeds: $5 \mathrm{~km} / \mathrm{h}, 10 \mathrm{~km} / \mathrm{h}$, $15 \mathrm{~km} / \mathrm{h}$ and $20 \mathrm{~km} / \mathrm{h}$, and different power levels supplied to the auxiliary devices. The calculation results for the speeds of $5 \mathrm{~km} / \mathrm{h}$ and $15 \mathrm{~km} / \mathrm{h}$ are shown in Figures 9 and 10, respectively. It was assumed that the trolleybus moved on a flat asphalt road (rolling coefficient $\mu=0.01)$ in windless weather $(\mu=0.4)$.

At the initial speed of $5 \mathrm{~km} / \mathrm{h}$, the power required to keep the auxiliary devices operative (high PS ON) while the trolleybus was running through catenary insulators (high PS ON signal) was $0.7 \mathrm{~kW}$ (Figure 9a). The supply voltage of the static converter did not drop below $400 \mathrm{~V}$, and the traction conditions ensuring passenger comfort were not affected. When the DC link of the traction inverter was loaded with the power of $1 \mathrm{~kW}$, voltage dropped below $400 \mathrm{~V}$, and the converters supplying the auxiliary devices switched off, as shown in Figure 9b. As can be seen in Figure 9c, increasing the capacitance of the inverter DC links to $50 \mathrm{mF}$ increased power consumption to $2.2 \mathrm{~kW}$. At the speed of $5[\mathrm{~km} / \mathrm{h}]$, there was no loss of energy in the braking resistor. It follows that, at low speeds, to use this method of supporting the operation of the auxiliary equipment of the trolleybus, it is necessary to switch off by software the equipment that cannot be supported due to the power consumed by it. Using this method and increasing the DC bus capacity of the traction inverter at $5 \mathrm{~km} / \mathrm{h}$, it is possible to provide the functionality required by the legal regulations. 

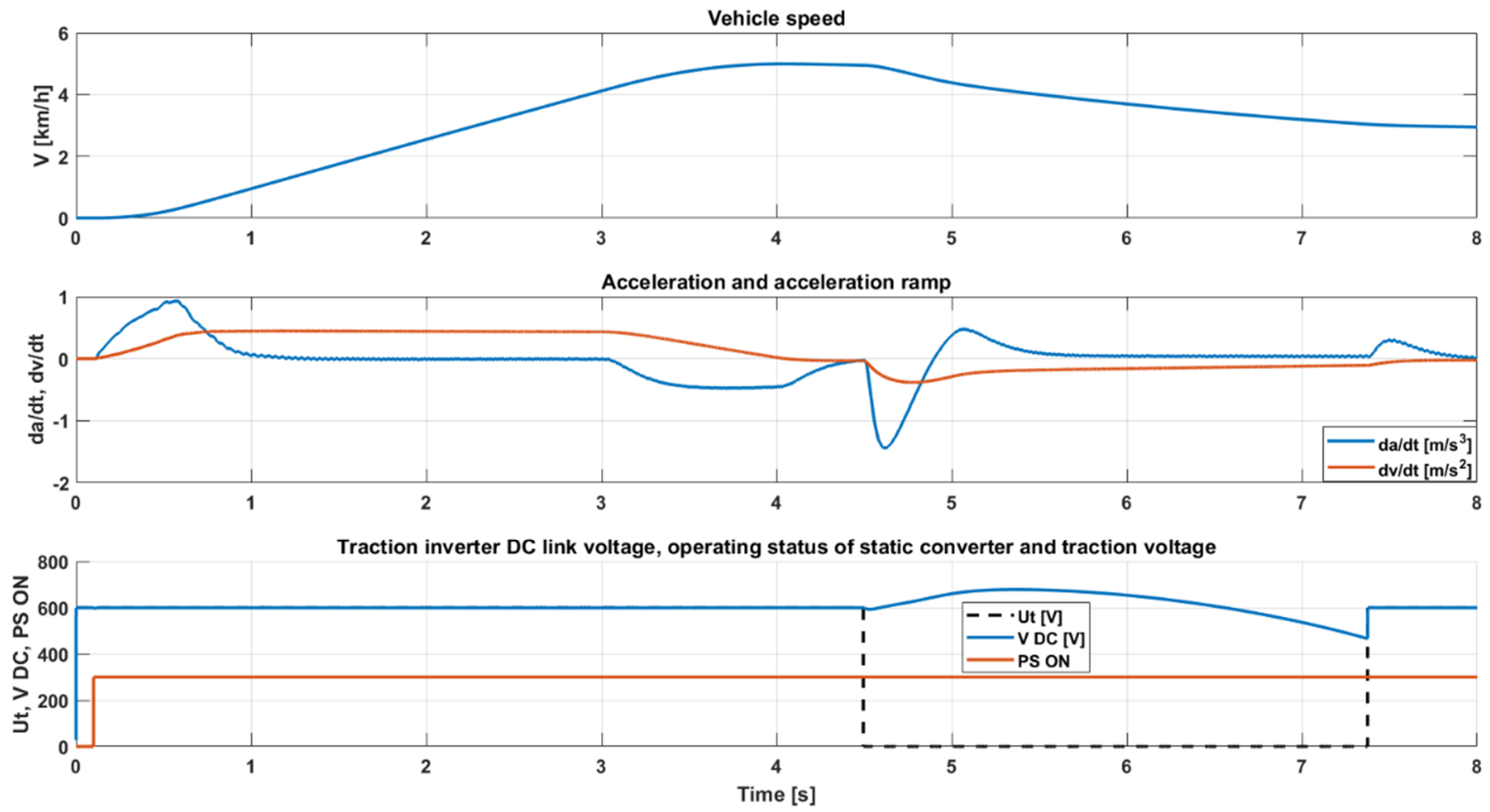

(a)

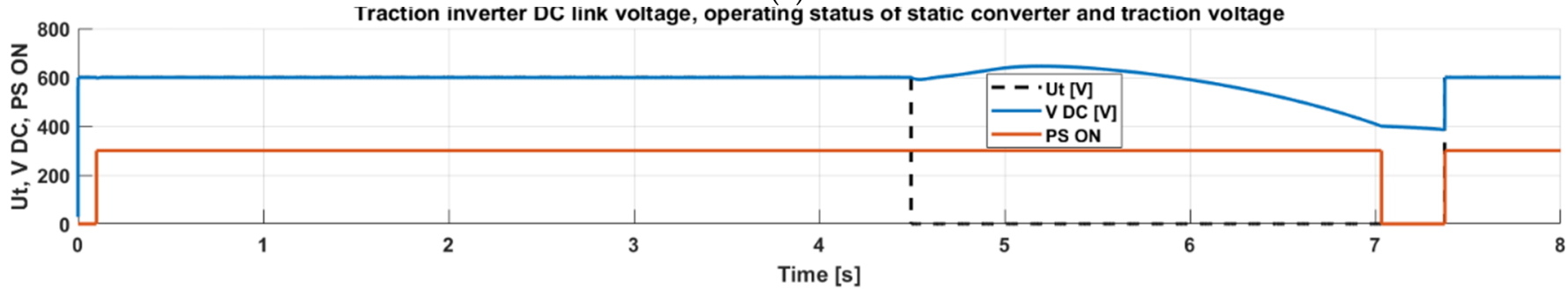

(b)

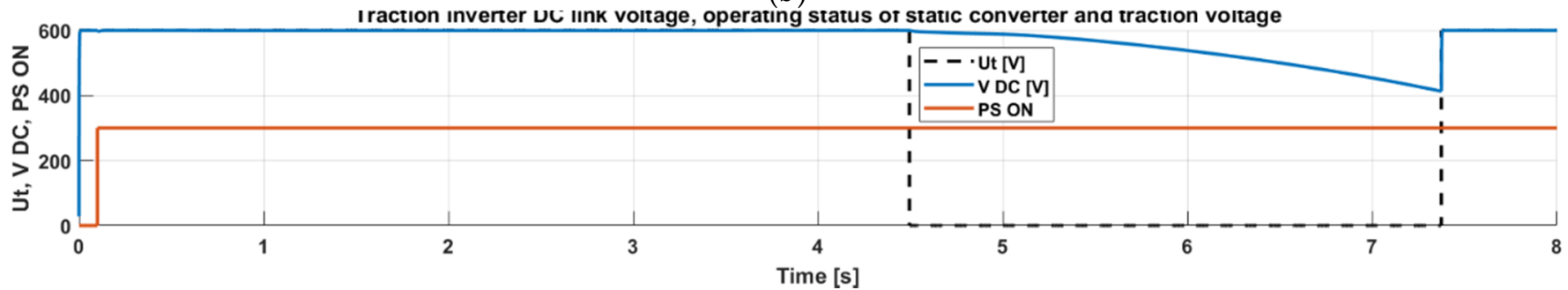

(c)

Figure 9. Simulation results for the initial speed of $5 \mathrm{~km} / \mathrm{h}$ and loads of (a) $0.7 \mathrm{~kW} \mathrm{C}$ d $=10 \mathrm{mF}$, (b) $1 \mathrm{~kW} \mathrm{C}$ d $=10 \mathrm{~m}$, and (c) $2.2 \mathrm{~kW} \mathrm{C}_{\mathrm{d}}=50 \mathrm{mF}$.

The power required to maintain the operation of auxiliary devices of the trolleybus passing through catenary insulators at the initial speed of $15 \mathrm{~km} / \mathrm{h}$ was $17 \mathrm{~kW}$ (Figure 10a). The flattening of the DC link voltage curve is a consequence of energy dissipation via the braking resistor at voltages above $780 \mathrm{~V}$. When the DC links were loaded with the power of $18 \mathrm{~kW}$ (Figure 10b), to ensure passenger comfort and attenuate the increase in braking torque, the voltage of the DC links fell below $400 \mathrm{~V}$ and the converters switched off. In the later phase of driving through the insulator, energy was lost in the braking resistor, and the converters supplying the auxiliary devices switched on. When the capacitance of the traction inverter DC links was increased to $50 \mathrm{mF}$ (Figure 10c), the power required to keep the auxiliary devices operative increased to $28 \mathrm{~kW}$. It follows that, at a speed of $15 \mathrm{~km} / \mathrm{h}$, the DC bus capacitance of the traction inverter must also be increased in order to 
ensure the continuity of operation of the auxiliary devices whose functionality is defined as required and additional. With a capacitance of $10 \mathrm{mF}$, it is necessary to disconnect some of the auxiliary devices by software in order to ensure continuity of power supply to the remaining devices.
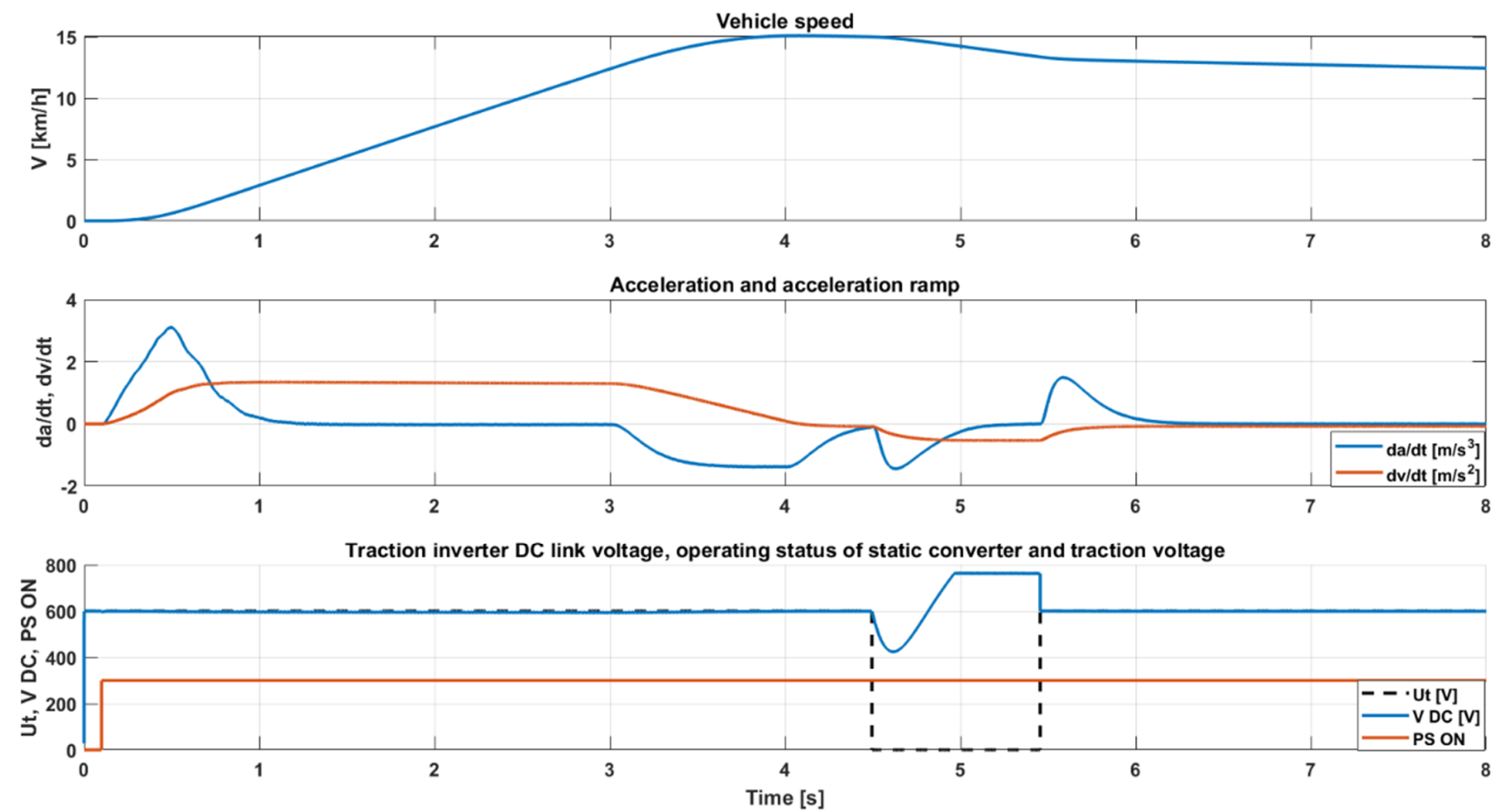

(a)

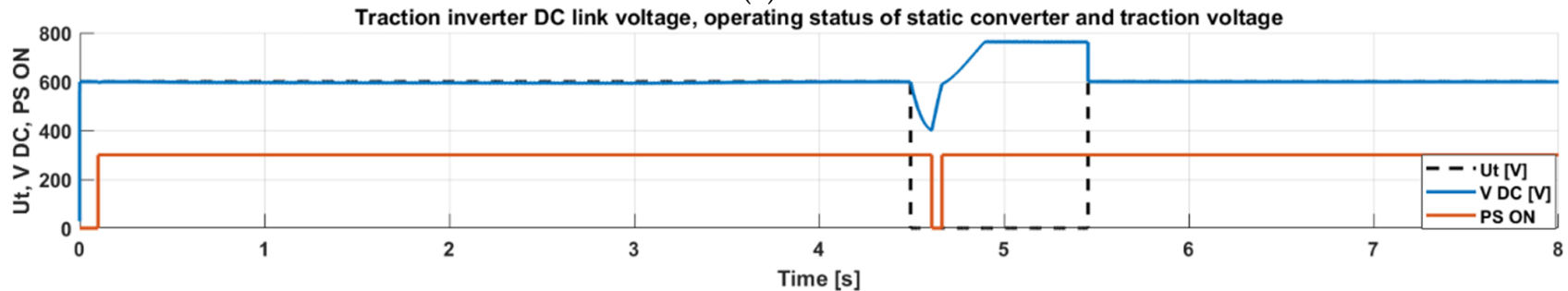

(b)

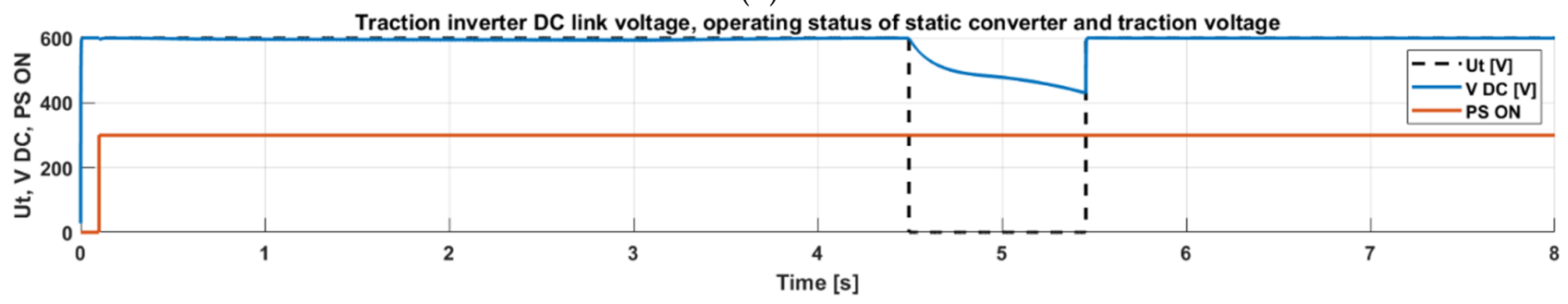

(c)

Figure 10. Simulation results for an initial speed of $15 \mathrm{~km} / \mathrm{h}$ and loads of (a) $17 \mathrm{~kW} \mathrm{C} \mathrm{d}_{\mathrm{d}}=10 \mathrm{mF},(\mathbf{b}) 18 \mathrm{~kW} \mathrm{C} \mathrm{d}=10 \mathrm{mF}$, (c) $28 \mathrm{~kW} \mathrm{C}$ d $=50 \mathrm{mF}$.

\section{Conclusions}

The paper presents an analysis of the possibility of powering on-board auxiliary devices of a trolleybus with energy from regenerative braking. It was determined, based on real-life and model data, how much power could be recuperated depending on the traction conditions and the capacitance of the traction inverter DC links. The simulation tests show that: 
- $\quad$ The power of the devices fed from the traction inverter DC links increases as the initial speed of the trolleybus grows

- The critical parameter that determines the maximum power of the devices fed from the DC links of the inverter is jerk, $d a / d t \leq 1.5 \mathrm{~m} / \mathrm{s}^{3}$

- At the vehicle speed of $v=5 \mathrm{~km} / \mathrm{h}$, power steering is operative only when the capacitance of the traction inverter DC links is considerably increased

- At the vehicle speed of $v=15 \mathrm{~km} / \mathrm{h}$, it was impossible to maintain the operation of all the devices powered by the static converter; to keep the devices operative, the capacitance of the traction inverter DC links had to be increased five-fold.

In summary, it should be stated that as the demand for power supplied to auxiliary devices in trolleybuses constantly increases, the method of powering auxiliary devices considered in this paper is effective only for a limited range of vehicle speeds and powers of these devices. This means that new power supply solutions for an extended range of operating conditions should be looked for.

A summary of the simulation results is presented in Figure 11 as a curve of the power that was sufficient to maintain the operation of the auxiliary devices of a trolleybus running through a $4[\mathrm{~m}]$ section insulator versus initial trolleybus speed. The curve was plotted for a traction inverter DC link capacitance of $10 \mathrm{mF}$ and a line voltage of $600 \mathrm{~V}$. The slope of the curve is a consequence of the adopted reaction time of the system to the detection of line voltage loss (5 ms), as well as the constraints on the driving dynamics parameters related to passenger comfort requirements, especially with regard to negative accelerations.

Due to the large influence of the DC bus volume of the traction inverter on the possibility of maintaining the continuity of power supply to the auxiliary equipment of the trolleybus, further research will concern the possibility of using supercapacitors in the intermediate circuit of the static converter and the search for topologies of the trolleybus drive systems, so that it is possible to use autonomous energy sources installed in the trolleybus.

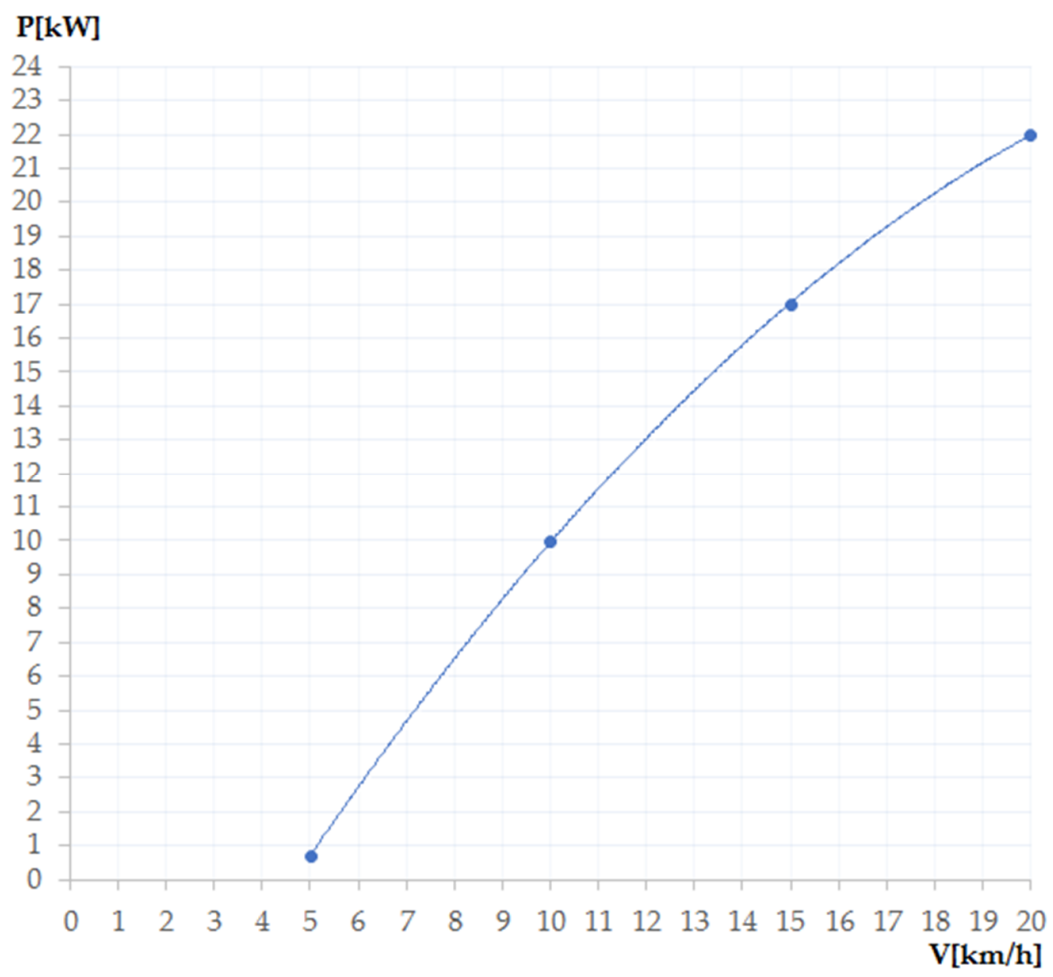

Figure 11. Power of auxiliary devices supplied from DC links as a function of speed at a traction inverter DC link capacitance of $10 \mathrm{mF}$. 
Author Contributions: Conceptualization, P.H. and D.Z.; Data curation, P.H.; Funding acquisition, P.H. and D.Z.; Methodology, J.R.; Resources, J.R.; Supervision, A.N.; Validation, E.D. All authors have read and agreed to the published version of the manuscript.

Funding: This research received no external funding.

Institutional Review Board Statement: The study did not involve humans or animals.

Informed Consent Statement: Not applicable.

Data Availability Statement: The study did not report any data.

Conflicts of Interest: The authors declare no conflict of interest.

\section{References}

1. Destraz, B.; Barrade, P.; Rufer, A.; Klohr, M. Study and simulation of the energy balance of an urban transportation network. In Proceedings of the European Conference on Power Electronics and Applications, Aalborg, Denmark, 2-5 September 2007; pp. 1-10.

2. Falvoa, M.C.; Lamedica, R.; Bartoni, R.; Maranzano, G. Energy management in metro-transit systems: An innovative proposal toward an integrated and sustainable urban mobility system including plug-in electric vehicles. Electr. Power Syst. Res. 2011, 81, 2127-2138. [CrossRef]

3. Foiadelli, F.; Roscia, M.; Zaninelli, D. Optimization of storage devices for regenerative braking energy in subway systems. In Proceedings of the IEEE Power Engineering Society General Meeting, Montreal, QC, Canada, 18-22 June 2006; p. 6.

4. Niewczas, A.; Rymarz, J.; Dębicka, E. Stages of operating vehicles with respect to operational efficiency using city buses as an example. Eksploatacja i Niezawodność Maint. Reliab. 2019, 21, 21-27. [CrossRef]

5. Połom, M.; Piasecki, A.; Bartłomiejczyk, M. Charakterystyka autonomiczności trolejbusów—Nowe doświadczenia w elektromobilności miejskiej. Logistyka 2015, 4, 6-14.

6. Scarpellini, S.; Valero, A.; Llera, E.; Aranda, A. Multicriteria analysis for the assessment of energy innovations in the transport sector. Energy 2013, 57, 160-168. [CrossRef]

7. Castro, R.; Pinto, C.; Araujo, R.E.; Melo, P.; Freitas, D. Optimal sizing and energy management of hybrid storage systems. IEEE Veh. Power Propuls. Conf. 2012, 10, 321-326.

8. Hołyszko, P.; Filipek, P.Z. Estimation of the running costs of autonomous energy sources in trolleybuses. J. Ecol. Eng. 2016, 17, 101-106. [CrossRef]

9. García, P.; Torreglosa, J.P.; Fernández, L.M.; Jurado, F. Control strategies for high-power electric vehicles powered by hydrogen fuel cell, battery and supercapacitor. Expert Syst. Appl. 2013, 40, 4791-4804. [CrossRef]

10. Iannuzzi, D.; Ciccarelli, F.; Lauria, D. Stationary ultracapacitors storage device for improving energy saving and voltage profile of light transportation networks. Transp. Res. C 2012, 21, 321-337. [CrossRef]

11. Jarzyna, W.; Zielinski, D.; Holyszko, P. Battery-supported trolleybus traction network-A component of the municipal smart grid. In Environmental Engineering $V$, 1st ed.; CRC Press/Balkema: Leiden, The Netherlands, 2017.

12. Gao, Z.; Fang, J.; Zhang, Y.; Jiang, L.; Sun, D.; Guo, W. Control of urban rail transit equipped with ground-based supercapacitor for energy saving and reduction of power peak demand. Int. J. Electr. Power Energy Syst. 2015, 67, 439-447. [CrossRef]

13. Barrero, R.; Mierlo, J.V.; Tackoen, X. Energy savings in public transport. IEEE Veh. Technol. Mag. 2008, 3, 26-36. [CrossRef]

14. Jiang, Y.; Liu, J.; Tian, W.; Shahidehpour, M.; Krishnamurthy, M. Energy harvesting for the electrification of railway stations: Getting a charge from the regenerative braking of trains. IEEE Electrif. Mag. 2014, 3, 39-48. [CrossRef]

15. Wang, C.; Nguyen, H. Steady-state voltage profile and long-term voltage stability of electrified road with wireless dynamic charging computer science. Engineering 2019, 19, 165-169.

16. Faggioli, E.; Rena, P.; Danel, V.; Andrieu, X.; Mallant, R.; Kahlen, H. Supercapacitors for the energy management of electric vehicles. J. Power Sources 1999, 84, 261-269. [CrossRef]

17. Bartłomiejczyk, M. Super capacitor energy bank MEDCOM UCER-01 in Gdynia trolleybus system engineering. In Proceedings of the Computer Science IECON 2016-42nd Annual Conference of the IEEE Industrial Electronics Society, Florence, Italy, 23-26 October 2016.

18. Rogge, M.; Wollny, S.; Sauer, D.U. Fast charging battery buses for the electrification of urban public transport-A feasibility study focusing on charging infrastructure and energy storage requirements. Energies 2015, 8, 4587-4606. [CrossRef]

19. Gizinski, Z.; Gasiewski, M.; Mascibrodzki, I.; Zych, M.; Zymmer, K.; Zulawnik, M. Hybrid-type system of power supply for a trolleybus with an asynchronous moto. In Proceedings of the 13th International Power Electronics and Motion Control Conference, Poznań, Poland, 1-3 September 2008.

20. Bartlomiejczyk, M.; Holyszko, P.; Filipek, P. Measurement and analysis of transmission losses in the supply system of electrified transport. J. Ecol. Eng. 2016, 17, 64-71. [CrossRef]

21. Hołyszko, P. Ocena metod zapewnienia ciagłości pracy urządzeń pomocniczych trolejbusu. In Wybrane Zagadnienia z Zakresu Elektrotechniki, Inżynierii Biomedycznej i Budownictwa: Prace Doktorantów Politechniki Lubelskiej; Biblioteka Politechniki Lubelskiej: Lublin, Poland, 2019. 
22. Ringdorfer, M.; Horn, M. Development of a wheel slip actuator controller for electric vehicles using energy recuperation and hydraulic brake control. In Proceedings of the IEEE International Conference on Control Applications (CCA), Denver, CO, USA, 28-30 September 2011; pp. 313-318.

23. Dziubinski, M.; Siemionek, E.; Adamiec, M.; Drozd, A.; Kołodziej, S. Energy consumption of the trolleybuses. In Proceedings of the 2017 International Conference on Electromagnetic Devices and Processes in Environment Protection with Seminar Applications of Superconductors, Naleczow, Poland, 3-6 December 2017; pp. 1-4.

24. Siemionek, E.; Dziubinski, M. Testing energy consumption in the trolleybus and the bus on a chosen public transport line in Lublin. Adv. Sci. Technol. Res. J. 2015, 9, 152-153. [CrossRef]

25. Hamacek, Š.; Bartłomiejczyk, M.; Hrbáč, R.; Mišák, S.; Stýskala, V. Energy recovery effectiveness in trolleybus transport. Electr. Power Syst. Res. 2014, 112, 1-11. [CrossRef]

26. Tazerart, F.; Mokrani, Z.; Rekioua, D.; Rekioua, T. Direct torque control implementation with losses minimization of induction motor for electric vehicle applications with high operating life of the battery. Int. J. Hydrog. Energy 2015, 40, 13827-13838. [CrossRef]

27. Thounthonga, P.; Rael, S.; Davat, B. Energy management of fuel cell/battery/supercapacitor hybrid power source for vehicle applications. J. Power Sources 2009, 193, 376-385. [CrossRef]

28. Radulescu, V.; Strainescu, I.; Moroianu, L.C.; Serbu, V.; Tudor, E.; Gheorghe, S.; Goia, C. Driving equipments made by ICPE SAERP for urban electric transport vehicles. In Urban Transport XIV: Urban Transport and the Environment in the 21st Century; Wit Transactions on the Built Environment: Southampton, UK, 2008; Volume 114, pp. 562-572. 